\title{
POTENTIAL RESOURCES, LOCAL COMMUNITIES' ATTITUDES AND PERCEPTIONS FOR OUTDOOR RECREATION AND ECOTOURISM DEVELOPMENT IN URBAN FRINGE HAREGO AND BEDEDO CONSERVED FOREST, SOUTH WOLLO ZONE, ETHIOPIA
}

\author{
Tesfaye Fentaw NIGATU* \\ Wollo University, Tourism and Hotel Management Department, Ethiopia, e-mail: tesfaye.fentaw@wu.edu.et \\ Asnakew Atlug TEGEGNE \\ Wollo University, Tourism and Hotel Management Department, Ethiopia, e-mail: asnutour21@ gmail.com
}

\begin{abstract}
Citation: Nigatu, T.F., \& Tegegne, A.A. (2021). POTENTIAL RESOURCES, LOCAL COMMUNITIES' ATTITUDES AND PERCEPTIONS FOR OUTDOOR RECREATION AND ECOTOURISM DEVELOPMENT IN URBAN FRINGE HAREGO AND BEDEDO CONSERVED FOREST, SOUTH WOLLO ZONE, ETHIOPIA. GeoJournal of Tourism and Geosites, 39(4spl), 11421-1429. https://doi.org/10.30892/gtg.394spl13-786
\end{abstract}

\begin{abstract}
The study identified the potential resources and examined the local communities' attitudes and perception towards outdoor recreation and ecotourism development in the urban fringe Harego and Bededo conserved forest, Ethiopia. Mixed research approach was applied along with descriptive and sequential explanatory design. Questionnaire, interview and personal observations were data gathering instruments. Consequently, 336 respondents were randomly selected while key informants were selected purposefully. Simple descriptive analysis, crosstabs and independent t test has been applied to analyze the quantitative data while the qualitative data was analyzed using interpretative analysis technique. The study revealed that the areas have plethora of fauna and flora resources, amazing landscapes and are huge potentials for outdoor recreation and ecotourism development. More significantly, there is positive attitude and perception from the local people which is important for outdoor recreation and ecotourism, their intentions of direct involvement for the development necessities are also very promising while there is a statistically significant difference between high school and below holders (Mean=18.11, sig. 0.001) and college diploma and above holders (Mean=20.89, sig. 0.001).
\end{abstract}

Key words: ecotourism, outdoor recreation, perception, attitude, urban fringe and conserved forest

$* * * * * * *$

\section{INTRODUCTION}

According to the International Union of Conservation of Nature (IUCN), Ecotourism, outdoor recreation activities and protected areas are closely integrated and thus, majority of the ecotourism and outdoor recreational activities were conducted in protected areas (Poffenberger, 1996). The International Ecotourism Society defines ecotourism as "a responsible travel to natural areas that conserves the environment, sustain the wellbeing of the local people, and involves interpretation and education', (Haloi et al., 2017). Different forms of outdoor recreational activities including watching wildlife, photography, health and relaxation, games, study, educational activities and conservational practices are performed in protected areas (Goharipour and Hajiluie, 2016). Hence, dealing about ecotourism, linking tourism with environment and local communities' interest is highly important as a sustainable form of tourism.

As one form of nature based tourism, ecotourism and outdoor recreation are fast growing industries (Bell et al., 2007). Based on the report of United Nation World Tourism Organization, ecotourism covers 10-15\% of the tourism industry share. By its nature ecotourism relied on natural resources and the driving force of environmental education, conservation of local culture and natural environment, ensure economic benefit of the local and the sustainable development of the areas (Golubeva et al., 2016). In the century of the cities and urbanization, many people become less and less connected with the rural land. Consequently, many people are seeking to regain a connection with nature and with wild landscapes and forested areas to participate in different outdoor recreation and ecotourism activities. The participation of local communities in protected area management is also key factor in the long-term conservation of the natural resources (Asmamaw and Verma, 2013). Protected areas managed as ecotourism sites play a significant role in generating much needed revenue to pay for conservation of biological diversity as well as improving the financial income of the local communities (Abeli, 2017). However, protected areas have been vulnerable by human induced factors resultant from growing human development activities around residents (Eshetu, 2014). Perhaps, these days local community involvement in tourism is intricate part of research paradigm because the primary objective of community involvement in tourism is to assimilate locals into viable economic systems while there is little evidence that portrays the nature of interaction between local communities and tourism development (Mudimba and Tichaawa, 2017). But still the number of studies on local community attitudes towards future tourism development is increasing due to the nexus between community support and government future development emphasis on tourism (Hanafiah et al., 2013).

\footnotetext{
* Corresponding author
} 
Community involvement emerged as a key element of both sustainable tourism and ecotourism, and hence agreed to include public participation in decision-making and residents' benefits from tourism. Therefore, studying the local communities' attitudes is a key factor for tourism planning and development in general (Harun et al., 2018), and helps to identify the factors that influences their perceptions for ecotourism development in particular (Tesfaye, 2017). Because knowing local communities' attitude towards tourism development and the impacts can help practitioners to identify real concerns and issues for appropriate policies and action to be taken (Adeleke, 2015). Likewise, perceptions and attitudes are understood to be important experiences of people's behavior in relation to resources management or conservation (Tadesse and Teketay, 2017). In many situations there is a conflicted relationship between local communities, tourists and protected areas (Asmamaw and Verma, 2013; González-Ramírez et al., 2019).

Some have positive attitude for protected areas around while others have negative perception towards conservation of protected areas and ecotourism development. For instance, residents who perceive a greater level of economic gain or personal benefit from ecotourism seem to have positive perceptions towards it (Türker and Öztürk, 2013; San Martin Gutierrez et al., 2018). On the contrary, the perceptions and attitudes of others are negative because people living near protected areas have subsistence needs that are direct opposition to the needs of the protected areas (Asmamaw and Verma, 2013). This goes to the essence of social applied theory in tourism which implied that the local communities attitude and participation is determined and improved with the benefit that those populations receive from involving directly in from the destination (Adeleke and Nzama, 2013; Harun et al., 2018). There are also other factors influencing the perceptions of residents at the tourist destination such as personal characteristics and expectations (Robbins and Coulter, 2005); extrinsic factors like tourism stage of development (Butler, 1980), seasonality, tourist type, economic dependency on tourism and degree of cultural differences between host and guest (Türker and Ozturk, 2013).

Although the factors influencing residents' perception about tourism have been extensively investigated (Harum et al., 2018; Assante et al., 2012; Robbins and Coulter, 2005), it becomes necessary to replicate studies in various locations and at different points (González-Ramírez et al., 2019), critical element in determining the tourism development, not overemphasized. Therefore, in the present world the number of research on local community attitudes and perceptions for any future tourism development shall be increased due to its significance to judge tourism appropriateness for particular communities (Abas and Hanafiah, 2014). Thus, the roles of communities for any tourism development in a particular area are critical and cannot be overemphasized (Fridgen, 1991, as cited in Nchor and Agbor, 2018). It is obvious to create different perceptions about the ecotourism and its impacts among the community members who live in the same destination (Gnanapala and Kaninathilaka, 2016). Even though Ethiopia has more than 40 protected areas established to conserve biodiversity and enhance eco-tourism, the value given to protected areas development is very low as compared to countries which are involved with similar activities such as Kenya, Tanzania and South Africa (Fetene et al., 2012). The same is true in the surrounding areas of Harego and Bededo conserved forest.

The local communities' perception and attitude towards outdoor recreation and ecotourism development in the surroundings of Harego and Bededo conserved forest are not studied previously and the ecotourism potentials of the areas remain untapped. More significantly, the town of Dessie, the seat of south Wollo zone administration, is situated in the foot of mountain relatively a strategic place for outdoor recreation and ecotourism development. On the other hand, the number of population and rural to urban migration is too high in the surrounding towns (Dessie, Kombolecha and other small towns like Haik and Sulela) and hence, the people in the town demand fresh air from the surrounding protected forests to escape from urban traffic. Therefore, the study tried to identify the potential ecotourism and outdoor recreation resources and products and the local communities' perceptions and attitudes towards outdoor recreation and ecotourism development in the urban fringe protected areas of Harego and Bededo conserved forest, South Wollo Zone, Ethiopia.

\section{Objectives of the study}

$>$ To assess the tourism potentials of Harego and Bededo conserved forest for outdoor recreation and ecotourism development

$>$ To examine the attitudes and perceptions of local communities towards outdoor recreation and ecotourism development in the study areas.

\section{LITERATURE REVIEW}

The study of local community perspectives of tourism is started from 1980s (Rasoolimanesh and Jaafar, 2016), while today's intention is the casual relationships (Çelik and Rasoolimanesh, 2021). Tourism has undergone a tremendous growth for the last decades worldwide with the important role of local communities' attitudes and perception for sustainable tourism (Harun et al., 2018). The ever increasing competitions of land today are putting huge pressure on protected areas so that positive attitude and perception for protected areas are equally important. However, the positive attitude towards it is very limited (Bragagnolo et al., 2016). Not every local resident has the same perception and attitude toward tourism. It would rather depend on the dependency on the sector as well as the degree of involvement (GonzálezRamírez et al., 2019; San Martin Gutierrez et al., 2018; Türker and Ozturk, 2013) as well as the impact of tourism development on the community (Rasoolimanesh et al., 2017). Study conclude that, while residents who are entrepreneurs tend to prioritize the financial profits stemming from tourism development, the rest of the community places the emphasis on non-economic aspects (Cawley and Gillmor, 2008; González-Ramírez et al., 2019). The author grouped local residents' perception and attitude factors into intrinsic such as socio demographic characteristics, involvement to the tourism sector) and extrinsic factors including cultural difference, seasonality, tourism development level and the like. 
According to Balogu (1998), attitude has three interrelated components: cognition (perceptions/belief), affective (feelings) and conation (behavioral intentions). Considering the traditional approach of attitude, residents attitude towards tourism are enduring predisposition towards the tourism development is either positive if the benefits of tourism development exceeds the cost or negative if the cost of tourism exceeds the benefit (San Martin Gutierrez et al., 2018) and more significantly, the equitable share of the benefits (Kariuki, 2013). This is related with the social exchange theory developed by sociologist George Homas in 1958 that mostly focused on the relationship between the host community and tourism development in tourism concept (Rua, 2020). Moreover, local communities' attitude and perception can be also influenced by socio economic factors including age, gender, income, race and educational status (Kariuki, 2013).

\section{MATERIALS AND METHODS}

\section{Description of the study areas}

The study was conducted in the urban fringe areas of Bededo and Harego conserved forest surrounding Dessie, Kombolcha and nearby small town of Sulula, Bededo, Qorke and Jeme, South Wollo zone, Ethiopia. The zone is found in Amhara Region and endowed with different historical, cultural and natural attractions including Dessie Museum, Nigus Mikael complex, battle field and historic site of Mekedela Amba, Boru Meda historic site, historic site of Yisma Niguse, Jema Negus Mosque, Tedibabe Mariyam and its environs, Tenta St. Mikael church, Gishen Debre Kerebie Monastery, Lake Aredibo and Haiq, Borena Sayint Worhimeno National park, Woleqa Abay Tasabi Park, Yegof mountain, Harego and Bededo protected forests, Tossa Mountain and many more which can entertain, amaze and create breathtaking feeling for tourists (Amhara Culture, Tourism and Parks Development Bureau, 2011; South Wollo zone culture and tourism office, 2019; Teklie, 2011).

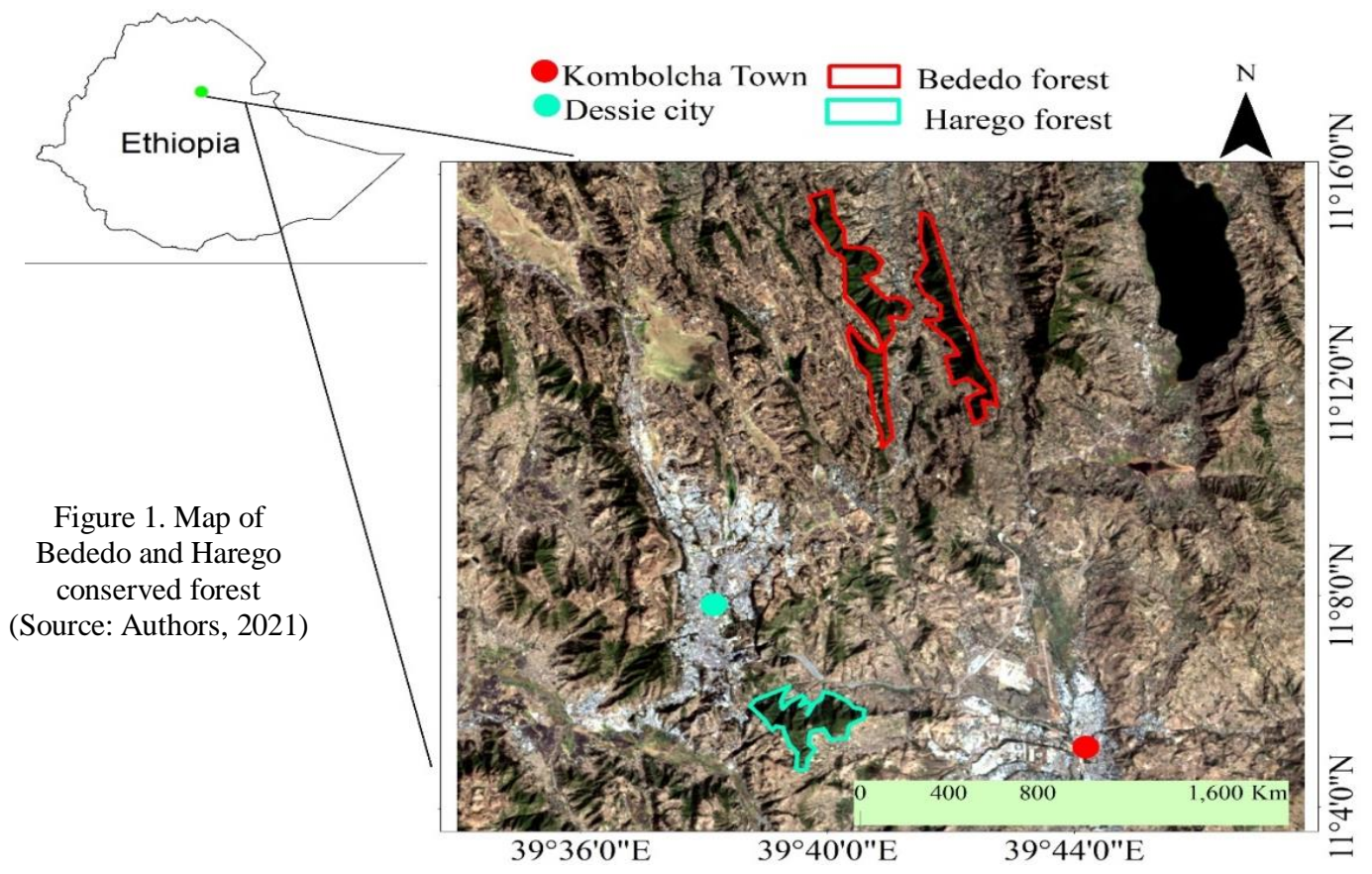

\section{Study Approach and Design}

In this research the potential resources were identified and the perceptions and attitudes of local communities towards outdoor recreation and ecotourism development are analyzed. To do so, the study employed a systematic and scientific investigation of qualitative and quantitative properties of phenomena along with descriptive and sequential explanatory research design.

\section{Types and Sources of Data}

In an attempt to do the research more wide-ranging and constructive, the researchers used secondary and primary data. The secondary data has been used to construct a detailed and comprehensive literature review from published sources, thesis and government reports to state the problem clearly. Literatures were collected from different research articles related with the community participation, perception and attitude for tourism development in general and ecotourism and outdoor recreation activities in particular. Primary data were collected by using interview, questionnaire and observation tools. In order to extract detailed and important data about the tourism potentials of the areas, the researchers prepared semi structured interview questions. Interview was conducted with 26 experts from culture and tourism offices, agriculture and environment conservation offices, rural kebele leaders and local administrators. On the other hand, open and closed ended questionnaire was prepared because closed-ended questions used to enable the researchers to examine people's response on specific pre-coded aspects, while open questions are particularly useful for identifying the reasons why a particular respondent held such a point of view on a particular aspect (Long, 2007). Thus, three point Likert scale questionnaire was distributed to the households to examine their perceptions and attitudes towards outdoor recreation and ecotourism development. In the three Likert scale questionnaire 1 stands for disagreement, 2 represents neither disagree nor agree and 3 stands for agreement on the issue. Finally, the questionnaire was administered by the researchers and data collectors/enumerators. The researchers observed the sites in order to identify the potential resources of the area for 
ecotourism and outdoor recreation activities, the use of forests for the local communities and the type of ecotourism and outdoor activities more appropriate in the study areas. The data was recorded photographically and by note taking.

\section{Population, Sampling and Sample Size Determination}

For the effectiveness of this study simple random and purposive sampling technique was applied. Simple random sampling was employed to take representative samples from the local communities whereas purposive sampling was employed to select experts for interview. Based on South Wollo zone culture and tourism office (2019), the populations living in the surrounding area of the Harego and Bededo conserved forest are 10412 and by considering 5 individuals are living within a household, there are 2082 households around the study area. Consequently, 336 samples was determined and taken using Yemane (1967) formula.

$$
\mathrm{n}=\frac{\mathbb{N}}{\left.1+\mathrm{N}_{[\mathrm{e}]}\right]} \text {, where } \mathrm{n} \text { is sample size, } \mathrm{N} \text { is total target population, e is level of precision as presented in Yamane (1967). }
$$

\section{Data Analysis Plan}

Data analysis was conducted using Statistical Package for Social Sciences (SPSS) version 21 using descriptive statistics; percentage, mean and crosstabs. Moreover, inferential statistics particularly independent $t$ test was applied to investigate the perception and attitude of local communities on ecotourism and outdoor recreation benefits, willingness to involve in tourism business and to welcome tourists. The qualitative data collected from interview and observation was analyzed using interpretative analysis technique.

\section{Ethical considerations}

The researchers asked the respondents and reached at consensus in all manners to collect data. Moreover, all materials taken for the study are dully acknowledged.

\section{Results and Discussion}

Based on the sampling procedure described, from 336 distributed questionnaires, 309 questionnaires were properly filled and returned for analysis $(91.9 \%)$. The questionnaires contained mainly the demographic variables of the respondents, and the main questions related to the attitudes and perceptions of the local communities towards outdoor recreation and ecotourism development.
Table 1. Demographic profile of the respondents (Source: survey result, 2021)

\begin{tabular}{|l|c|c|c|}
\hline Variables & Category & Percentage & $\mathrm{N}$ \\
\hline \multirow{4}{*}{ Age } & $18-28$ & 26.5 & 82 \\
\cline { 2 - 4 } & $29-39$ & 35.3 & 109 \\
\cline { 2 - 4 } & $40-50$ & 23.9 & 74 \\
\cline { 2 - 4 } & $51-61$ & 12 & 37 \\
\cline { 2 - 4 } Gender & Above 62 & 2.3 & 7 \\
\cline { 2 - 4 } & Female & 31.4 & 97 \\
\hline \multirow{4}{*}{$\begin{array}{l}\text { Level of } \\
\text { education }\end{array}$} & $\begin{array}{c}\text { Male } \\
\text { Completed and below }\end{array}$ & 68.6 & 212 \\
\cline { 2 - 4 } & $\begin{array}{c}\text { College diploma and } \\
\text { above }\end{array}$ & 26.9 & 226 \\
\hline \multirow{4}{*}{$\begin{array}{c}\text { Source of } \\
\text { income }\end{array}$} & Agriculture & 34.3 & 106 \\
\cline { 2 - 4 } & Business & 21 & 65 \\
\cline { 2 - 4 } & Civil servant & 19.1 & 59 \\
\cline { 2 - 4 } & Self employed & 19.7 & 61 \\
\cline { 2 - 4 } & $\begin{array}{c}\text { Sale of plants or non- } \\
\text { timber products }\end{array}$ & 4.2 & 13 \\
\cline { 2 - 4 } & Sale of timber & 1.6 & 5 \\
\hline
\end{tabular}

\section{General Information about the respondents}

The demographic profiles of respondents were assessed in age, gender, level of education, and sources of income categories. As a result, the age distribution of respondents assessed in different age ranges; $26.5 \%$ of the respondents were aged from 18-28, 35.3\% aged from 29-39 and 23.9\% were from 40-50 while the remaining $14.3 \%$ were aged 51 and above. The results of the gender distribution of the community household also indicate that the majority of the respondents $(68.6 \%)$ were male whereas the remaining $31.4 \%$ were females. In response to the respondents level of education, $73.1 \%$ (226) were high school completed and below and $26.9 \%$ (83) were college diploma and above holders. The finding further suggests that the majority of the respondents had little education. Respondents were also asked their sources of income, and $34.3 \%$ were depend on agriculture while $21 \%$ are involved in small and medium scale business practices. Besides, $19.1 \%$ are civil servants and $19.7 \%$ are self-employed. The remaining $4.2 \%$ involved in sale of plants (non-timber) whereas $1.6 \%$ respondents are participated in sales of timber from the forest.

Potential Ecotourism and Outdoor Recreation Resources in Harego and Bededo Urban Fringe Conserved Forest

Based on the observations and interview, the study areas possess a huge potential for ecotourism and outdoor recreation destinations. These are due to the presence of abundance of fauna and flora resources and species which have a potential to attract visitors. The true potential of the areas has to date remain untapped and not effectively and efficiently explored for the development agenda of the local economy.

\section{Fauna Resources of the Study Areas}

The researchers' observation and key informants interview outlined that the areas possess the fauna species. Over 34 species of animals have been sheltered to date. According to the district agriculture officer, around 20 wild animal species are found only in Harego conserved forest. The most common animals are; Meneliks deer (Yeminilik dikula), Tiger (Nebre), Sesame (Sesa), Monkey (Zenejero) and Vervet Monkey (Tota), Rock Hyrax (shikoko), Echidna (Jart), and spotted hyena. Spotted hyena is very common animal species found in the study areas. Additionally, more than 90 species of birds are found in these two conserved forest. The most common were Crow (Qura), Guinea fowl (Jigera), Falcon (chilfite), Owl (gugut) and others bird species are listed (South Wollo zone culture and tourism office, 2019).

\section{Flora Resources of the Study Areas}

The areas also covered with majorly planted (more than $80 \%$ coverage) forests especially Harego conserved forest. 
The community representative and the district agriculture office confirmed that the forests are the effort of human being in the forestry science (Figure 2,3). The areas are covered with an indigenous trees of Juniperus procera (yehabesha Tsede in Amharic), Hagenia abyssinica (Bruce) J.F. Gmel (Koso in Amharic, Olea europaea subsp cuspidata (Wall. Ex DC.) Cifferri. (Woyera in Amharic), Euphorbia Candelabrum (Qulequal in Amharic), planted eucalyptus tree (Bahirzafe in Amharic), African Black wood or its scientific name is Dalbergia melanoxylon (Tikure enchete in Amharic), Dodonaea Angustifolia L.F (Sapindaceae) or Kitkita in Amharic, Erica arborea L. (Ericaceae) or Aseta in Amharic, Phytolacca dodecandra L'Herit (Phytolaccaceae) or Endod in Amharic, Rumex nervosus Vahl (Polygonaceae) or Embuacho in Amharic, Carissa spinarum L. (Apocynaceae) or Agam in Amharic, Podocarpus falcatus (Thun) Mirb or Zigba in Amharic, Acacia SPP or Girar in Amharic, Rosa abyysinica or Qega in Amharic trees.

All these plant species are found in Ethiopia only (South Wollo zone culture and tourism office, 2019). Therefore, the areas are the guarding place of indigenous trees of Ethiopia. Researchers believed that the areas give a good lesson for those barred land of Ethiopia because of its value on the conservation of indigenous trees through human effort (plantation) and hence, these resources create an idyllic and eye-catching place to visitors.

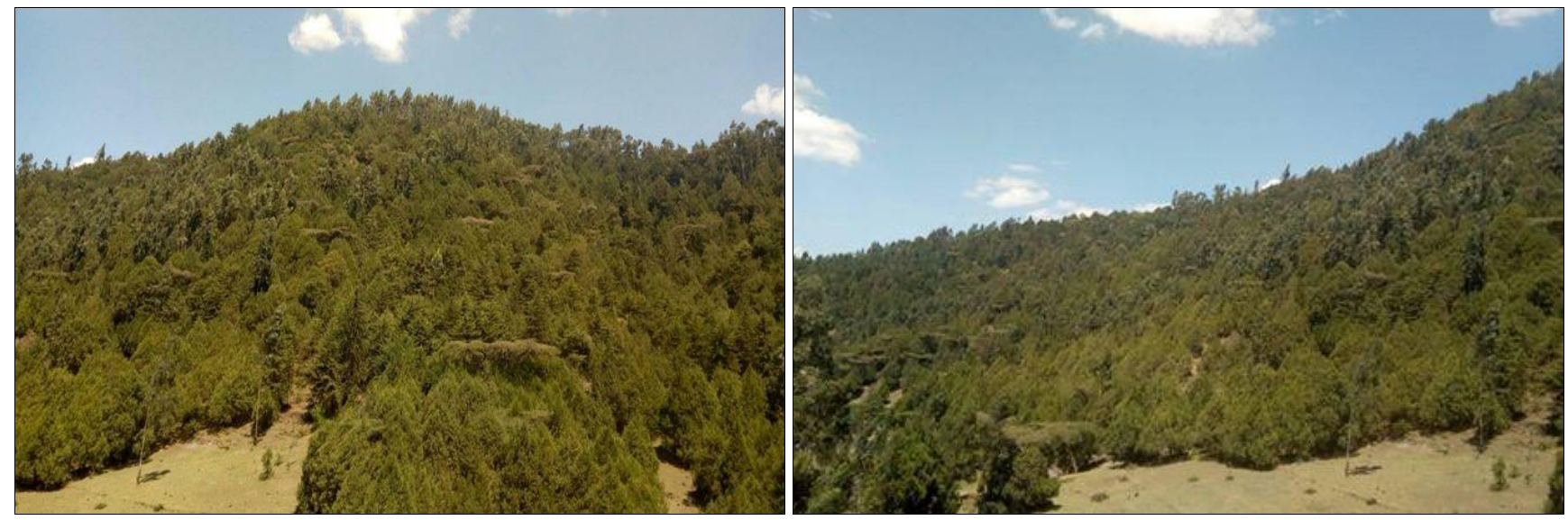

Figure 2. The scenic view of Bededo conserved forest (Source: Photo by researchers, 2021)
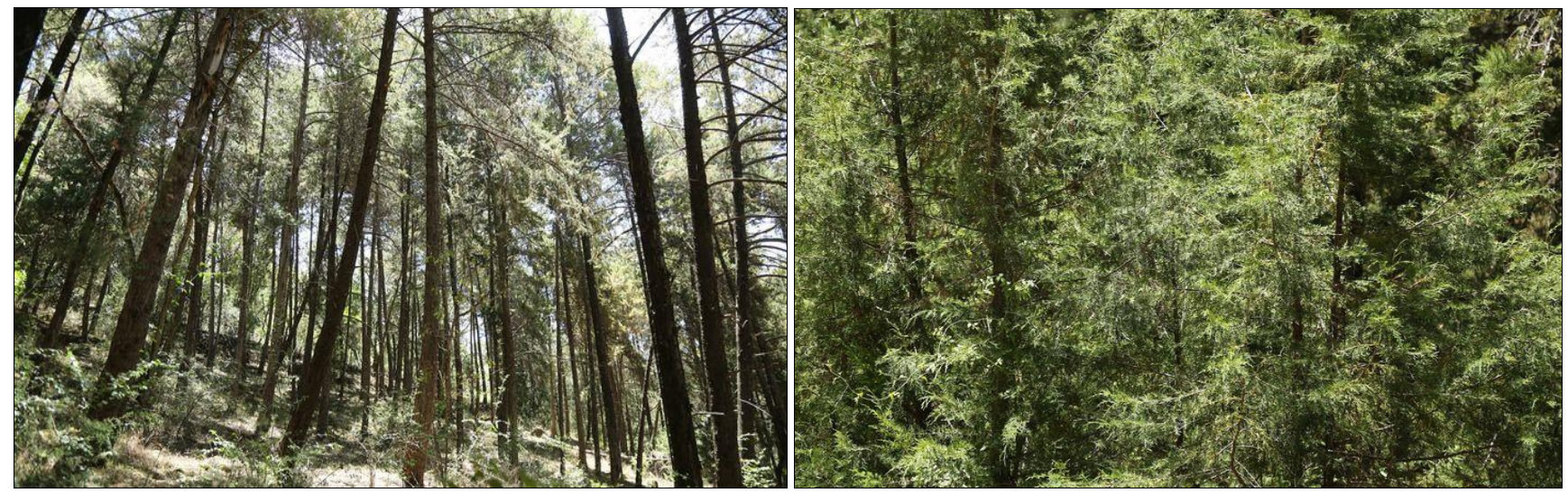

Figure 3. The indigenous Juniperus procera trees in Bededo (Source: Photo by the researchers, 2021)

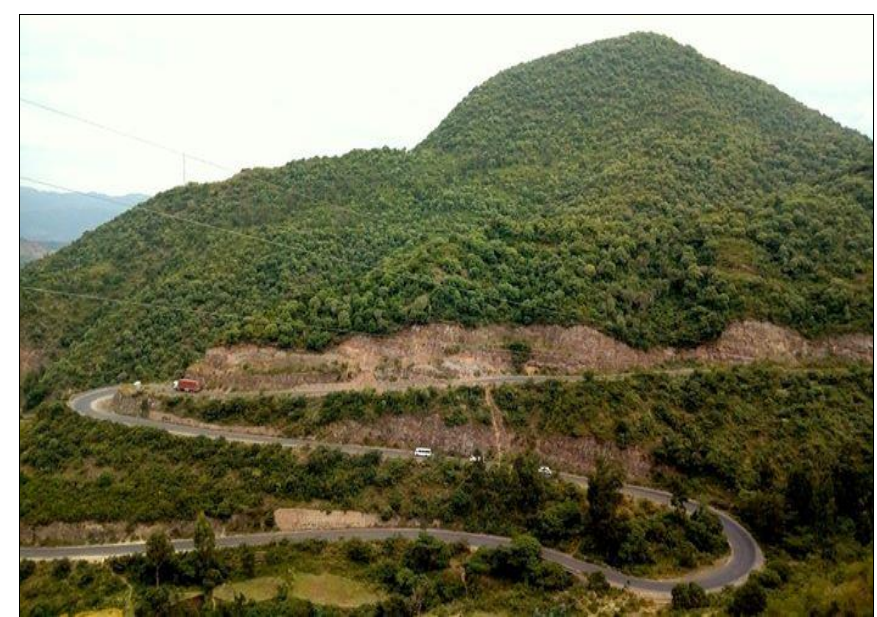

Figure 4. Harego road commonly known as" $S$ " road

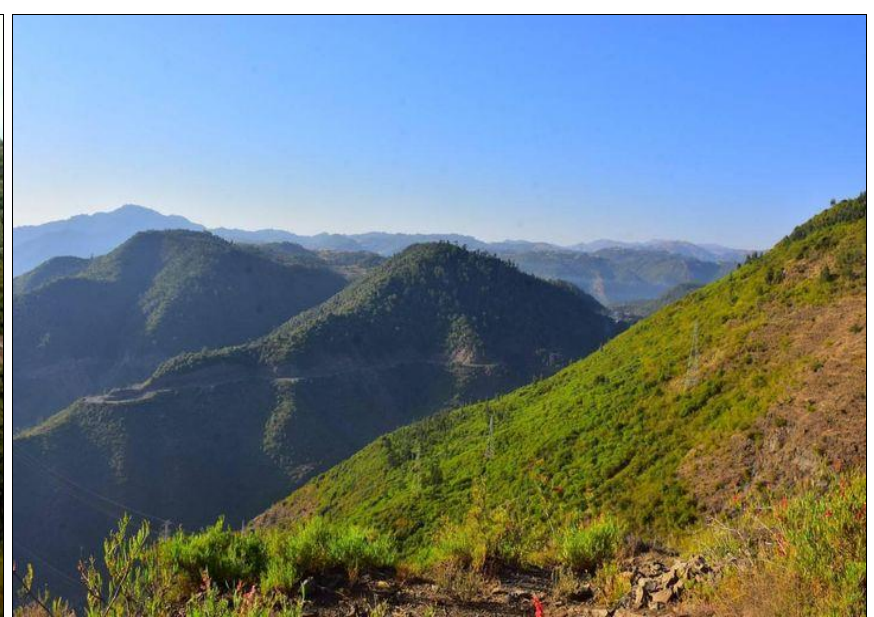

Figure 5. An aesthetically pleasuring Harego conserved forest (Source: Photo by Alemsged, 2020) 
Local communities' attitudes and perceptions towards outdoor recreation and ecotourism development

Local communities' attitude and perception plays significant role in determining the tourism development in the host destination. Consequently, in this study before measuring the perception and attitude of local communities towards outdoor recreation and ecotourism development, respondents were asked whether they know what ecotourism and outdoor recreation is. Thus, descriptive analysis particularly crosstabs were applied to analyze their knowhow about ecotourism and outdoor recreation. According to Table 2. Respondents understanding of ecotourism and outdoor recreation (Source: survey result, 2021)

Bragagnolo et al (2016), the most important predictor of knowledge related to protected area and tourism development is education followed by occupation. Knowledge is associated with the level of education and participation. Therefore, the present study sustained that respondents with better educational level had better understanding of what ecotourism and outdoor recreation mean. It was assessed based on the level of education of respondents (Table 1). Hence, 89.8\% and $92.9 \%$ of high school and below completed respondents replied that they didn't know what ecotourism and outdoor recreation mean and the remaining small percentage of respondents $(10.2 \%$ and $7.1 \%$ respectively) responded that they have knowhow about ecotourism and outdoor recreation.

On the other hand, college diploma and above completed respondents ( $86.7 \%$ and $96.4 \%$ respectively) reacted that they have understanding about ecotourism and outdoor recreation while $13.3 \%$ and $3.6 \%$ of respondents replied that they have no knowledge of it respectively. Consequently, the finding pertinently notes that high educational status determine the knowledge of tourism development at a destination (Ejiofor and Elechi, 2012). Moreover, as shown in the demographic variables, all respondents are involved in non-tourism activities since tourism is not yet developed well in the study area and this would contribute for no understanding of what ecotourism and outdoor recreation mean.

\section{Attitude and willingness of local communities to participate in ecotourism and outdoor recreation business activities}

To narrate the attitude and willingness of local communities to participate in ecotourism and outdoor recreation business activities, a three point Likert scale questionnaire was distributed in two sections (Harego and Bededo protected landscapes). Thus, respondents were asked their willingness to participate in ecotourism and outdoor recreation development and management activities and $57.6 \%$ of the respondents agreed with the idea, $20.7 \%$ refrained while the remaining $21.7 \%$ disagreed with the idea. On the same way, $45.3 \%$ of respondents reflected their willingness to engage in conservation of natural resources so as to develop outdoor recreation and ecotourism activities whereas $26.2 \%$ respondents neglect neutral. As indicated in the $3^{\text {rd }}$ row of table above, $62.8 \%$ of respondents were agreed to show their commitment to support new ecotourism and outdoor recreation facilities that will attract more tourist in the community while small number of respondents $(15.5 \%)$ disagreed with the statement. On the other hand, $21.7 \%$ were neutral or no concept for the statement. In the $4^{\text {th }}$ row of the table, respondents were also asked whether they are participating in illegal harvesting of forests in the protected areas or not and the majority of respondents (79.6\%) replied that they are not participated in illegal harvesting though small number of respondents $(9.4 \%)$ engaged in illegal harvesting. In ascertaining the local communities' willingness to support decisions on ecotourism and outdoor recreation development, only $11.4 \%$ of the respondents disagreed and $20.4 \%$ of respondents remained neutral. $68.3 \%$ of the respondents agreed that they are willing to support decisions on ecotourism and outdoor recreation development.

Table 3. Attitude and willingness of local communities to participate in ecotourism and outdoor recreation business activities (Source: survey result, 2021)

\begin{tabular}{|c|c|c|c|c|c|}
\hline \multirow{2}{*}{ Items } & \multirow{2}{*}{$\mathrm{N}$} & \multirow{2}{*}{ Mean } & \multicolumn{3}{|c|}{ Level of agreement in percentage } \\
\hline & & & Disagree & Neutral & Agree \\
\hline $\begin{array}{l}\text { I am willing to participate in ecotourism and outdoor recreation development and } \\
\text { management activities }\end{array}$ & 309 & 3.45 & 21.7 & 20.7 & 57.6 \\
\hline $\begin{array}{l}\text { I am willing to engage in conservation of natural resources so as to develop outdoor } \\
\text { recreation and ecotourism activities }\end{array}$ & 309 & 3.27 & 26.2 & 28.5 & 45.3 \\
\hline $\begin{array}{l}\text { I will support new ecotourism and outdoor recreation facilities that will attract more } \\
\text { tourist in my community }\end{array}$ & 309 & 3.62 & 15.5 & 21.7 & 62.8 \\
\hline I am not participating in illegal harvesting of forests in the protected areas & 309 & 3.87 & 9.4 & 11 & 79.6 \\
\hline I am willing to support decisions on ecotourism and outdoor recreation development & 309 & 3.79 & 11.4 & 20.4 & 68.3 \\
\hline I will be happy if I engage in ecotourism and outdoor recreation business & 309 & 3.85 & 13.4 & 20.1 & 71.9 \\
\hline I am willing to receive ecotourism and recreation management education and training & 309 & 3.86 & 10.4 & 11 & 78.6 \\
\hline Grand mean & & & & & \\
\hline
\end{tabular}

Table 4. Result of independent t test (Source: survey result, 2021)

\begin{tabular}{|c|c|c|c|c|c|c|c|}
\hline Items & Level of education & $\mathrm{N}$ & Mean & Std. Deviations & $\mathrm{F}$ & T- value & Sig. \\
\hline $\begin{array}{c}\text { Perception and attitude towards ecotourism } \\
\text { and outdoor recreation benefits }\end{array}$ & High school and below & 226 & 25.35 & 3.349 & \multirow{2}{*}{7.172} & -2.988 & .008 \\
\cline { 2 - 5 } & College diploma and above & 83 & 26.69 & 3.838 & & \\
\hline
\end{tabular}


Furthermore, $71.9 \%$ of the respondents will be happy if they engage in ecotourism and outdoor recreation business whereas $13.4 \%$ disagreed that they have no demand to engage in ecotourism and outdoor recreation services and $78.6 \%$ of the respondents are willing to receive ecotourism and recreation management education and training. On the other way, in order to reveal the average perception and attitudes of local communities towards outdoor recreation and ecotourism development based on their level of education, independent t-test was used.

As depicted in the independent $t$ test above, there is a mean difference between high school and below (25.35) (Std. deviation= 3.349) and college diploma and above (26.69) (std. deviation=3.838) holders in their perception and attitude towards ecotourism and outdoor recreation benefits. The Levene test of equality of variances and test for equality of means also confirmed that there is a statically significant difference between high school completed and below and college diploma and above with $\mathrm{F}$ score $=7.172$, $\mathrm{T}$ value $=-2.988$ and sig. $=.008$ with $\mathrm{P}<.05$. This implied that the college diploma and above holders have better understanding, perception and attitude towards ecotourism and outdoor recreation benefits in Harego and Bededo protected landscapes. The crosstabs result also supported that $86.7 \%$ and $96.4 \%$ of respondents having college diploma and above know what ecotourism and outdoor recreation mean respectively. The result pertained with the study conducted by Ejiofor and Elechi (2012), that local community with formal and high level of education had better understanding of their environment for tourism purpose.

Attitude and Perception of local communities towards ecotourism and outdoor recreation benefits

In order to gain a better understanding of the perceptions and attitude of local communities towards ecotourism and outdoor recreation benefits respondents were asked whether outdoor recreation and ecotourism development can diversify employment opportunity for the locals. As a result, 51.7\% of the respondents agreed with the statement while $34.3 \%$ didn't believe with the concept and remained disagreed.

Despite the fact that ecotourism and outdoor recreation can be a livelihood option for the local, $49.6 \%$ of the respondents disagreed and didn't believe that it can be a livelihood option for the local communities. Only $33 \%$ of the survey respondents believed that ecotourism and outdoor recreation can be option to for the locals' economy.

Table 5. Perception and attitude of local communities towards ecotourism and outdoor recreation benefits (Source: survey result, 2021)

\begin{tabular}{|c|c|c|c|c|c|}
\hline \multirow[t]{2}{*}{ Items } & \multirow[t]{2}{*}{$\mathrm{N}$} & \multirow[t]{2}{*}{ Mean } & \multicolumn{3}{|c|}{$\begin{array}{l}\text { Level of agreemen } \\
\text { in percentage }\end{array}$} \\
\hline & & & 1 & 2 & 3 \\
\hline $\begin{array}{l}\text { Outdoor recreation and ecotourism development can diversify employment opportunity for the } \\
\text { community }\end{array}$ & 309 & 3.23 & 34.3 & 13.9 & 51.7 \\
\hline I believe ecotourism and outdoor recreation can be livelihood option for the local community & 309 & 2.76 & 49.6 & 17.5 & 33 \\
\hline Ecotourism and outdoor recreation improve the environment for future generations & 309 & 3.15 & 33 & 26.5 & 40.4 \\
\hline I know that protected areas are important for outdoor recreation and ecotourism development & 309 & 3.28 & 29.4 & 23.6 & 47 \\
\hline $\begin{array}{l}\text { I believe that ecotourism development is significant in environmental conservation of protected } \\
\text { areas and its ecosystem }\end{array}$ & 309 & 2.97 & 42.7 & 16.2 & 41.1 \\
\hline Ecotourism development helps to proud in culture through producing locally made products & 309 & 3.45 & 20.4 & 20.7 & 58.9 \\
\hline Grand mean & & & 3.14 & & \\
\hline
\end{tabular}

Of all respondents, $40.4 \%$ indicated that ecotourism and outdoor recreation improve the environment for future generations though $33 \%$ disagreed with the concept and $26.5 \%$ were neutral. Moreover, $47 \%$ know that protected areas are important for outdoor recreation and ecotourism development, $41.1 \%$ of them also believe ecotourism development is significant in environmental conservation of Harego and Bededo protected landscapes. $58.9 \%$ of the respondents believed that ecotourism development helps to proud in culture through producing locally made products in the areas.

Table 6. Result of independent $t$ test (Source: survey result, 2021)

\begin{tabular}{|c|c|c|c|c|c|c|c|}
\hline Items & Level of education & $\mathrm{N}$ & Mean & Std. deviation & $\mathrm{F}$ & T-value & Sig. \\
\hline le to & High school and below & 226 & 18.11 & 3.727 & \multirow{2}{*}{12.116} & \multirow{2}{*}{-5.526} & \multirow{2}{*}{.001} \\
\hline ind outdoor recreation business activities & College diploma and above & 83 & 20.89 & 4.431 & & & \\
\hline
\end{tabular}

It is important to have knowledge about the value which local communities attach to outdoor recreation and ecotourism development. The classic response of respondents' willingness and attitude to participate in ecotourism and outdoor recreation business activities showed that there is a mean difference between high school completed and below (18.11; Std. deviation=3.727) and college diploma and above (20.89, Std. deviation=4.431). The Levene test of equality of variances and t test for equality of means also articulated that there is a statically significant difference between high school completed and below and college diploma and above with $\mathrm{F}$ score $=12.116$, $\mathrm{T}$ value $=-5.526$ and sig. $=.001$ with $\mathrm{P}<.05$. This implied that the willingness and attitude of college diploma and above respondents is better to participate in ecotourism and outdoor recreation business activities in Harego and Bededo protected landscapes of south Wollo zone. The finding was consistent with the study conducted by Bragagnolo et al. (2016) that local attitude to ecotourism and protected areas are mainly shaped by education, gender and income.

Attitude and Perception of local communities to welcome tourists

In the group statistics and Levene test table, the mean of high school and below holders' perceptions and attitudes to 
welcome tourists is 9.423 with std. deviation of 2.515 for high school and below holders and the mean of college diploma and above holders are 10.90 with std. deviation 2.560. As depicted from the table the sig. value is 0.813 which is greater than 0.05 and this means that the perceptions and attitudes of the local communities to welcome tourists was not significantly different. Hence, all the respondents have good attitude and perception to welcome tourists to Bededo and Harego protected landscapes regardless of their educational level.

Table 7. Perception and Attitude of local communities to welcome tourists (source: survey result, 2021)

\begin{tabular}{|c|c|c|c|c|c|c|c|}
\hline Items & Level of education & $\mathrm{N}$ & Mean & Std, deviation & $\mathrm{F}$ & T-Value & Sig. \\
\hline Perception and attitude of local & High school and below & 226 & 9.42 & 2.515 & \multirow{2}{*}{.056} & \multirow{2}{*}{-4.587} & \multirow[t]{2}{*}{.813} \\
\hline communities to receive tourists & College diploma and above & 83 & 10.90 & 2.560 & & & \\
\hline
\end{tabular}

\section{CONCLUSION AND RECOMMENDATIONS}

The study focused on potential resources and the local communities' attitudes and perceptions towards outdoor recreation and ecotourism development in Harego and Bededo conserved forest, south Wollo, Ethiopia. The study concluded that; the areas were a huge potential for outdoor recreation and ecotourism development for both domestic and international visitors due to the presence of both fauna and flora resources. Because of its presents in the urban fringe areas; the sites will have prospect in outdoor recreation and ecotourism.

Consequently, the crosstabs result of the study outlined that the average understanding level of ecotourism and outdoor recreation is depend on the level of education of respondents. Thus, $89.9 \%$ and $92.9 \%$ of high school completed and below respondents didn't know what ecotourism and outdoor recreation mean while $86.7 \%$ and $96.4 \%$ of college diploma and above holders have the understanding of what ecotourism and outdoor recreation mean

The findings of the descriptive statistics also revealed that local communities have both positive and negative perceptions and attitude towards outdoor recreation and ecotourism. The grand mean (mean score $=3.67$ ) of attitude and willingness of local communities to participate in ecotourism and outdoor recreation business activities confirmed th at the local communities have positive perception and attitudes towards ecotourism development. On the same way, the grand mean score 3.14 shown that the local communities have good perception and attitude towards ecotourism and outdoor recreation benefits. Furthermore, the result of the independent $t$ test confirmed that the local communities of Harego and Bededo protected landscapes have positive and significant different between diploma and above holders and high school and below completed holders towards willingness and attitude to participate in ecotourism and outdoor recreation business activities and ecotourism and outdoor recreation benefits while the locals are equally willing to welcome tourists to their destination. From the conclusion the following recommendation were drawn.

- South Wollo zone culture tourism and sport department in collaboration with Wollo University shall develop the surrounding areas of Harego and Bededo protected landscapes for community based ecotourism site.

- Wollo University has to enhance awareness of the local communities through providing training on what ecotourism and outdoor recreation mean and its benefit.

- All stakeholders need to collaborate to develop the area as one tourist destination and to make it livelihood option.

\section{Acknowledgments}

The study is funded by Wollo University and hence the researchers would offer our appreciation to the university. Again the experts in tourism and agriculture offices at zonal, district and town level should be acknowledged for their cooperation and assistance.

\section{REFERENCES}

Abas, S.A., \& Hanafiah, M.H. (2013). Local community attitudes towards tourism development in Tioman Island. In 6th Tourism Outlook Conference, Kota Kinabalu Sabah, Malaysia, 22-24.

Abeli, S.R. (2017). Local Communities' Perception of Ecotourism and Attitudes towards Conservation of Lake Natron Ramsar site Tanzania. International Journal of Humanities and Social Science, 7(1), 162-176. https://www.ijhssnet.com/journals/Vol_7_ No_1_January_2017/15.pdf

Adeleke, B.O. (2015). Assessment of residents' attitude towards ecotourism in KwaZulu-Natal protected areas. International Journal of Culture Tourism and Hospitality Research. https://doi.org/10.1108/IJCTHR-12-2014-0102

Adeleke, B.O., \& Nzama, T. (2013). Assessment of Community Participation in Ecotourism and Conservation at Hhuhuwe-Umfolozi Park. Journal of Environment and Earth Science, 3(3), ISSN 2224-3216.

Asmamaw, D., \& Verma, A. (2013). Local attitudes towards environmental conservation and ecotourism around Bale Mountains national park, Ethiopia. Scholarly Journal of Agricultural Science, 3(11), 506-514.

Assante, L.M., Wen, H.I., Lottig, K., \& Hotels, S. (2012). An empirical assessment of residents' attitudes for sustainable tourism development: a case study of $\mathrm{O}$ ‘ahu, Hawai'i. Journal of sustainability and green business, 1(1), 1-27. https://www. researchgate.net/publication/265060537

Balogu, S. (1998). An empirical investigation of Attitude theory for tourist Destinations: a comparison of Visitors and non-visitors. Journal of hospitality \& tourism research, 22(3) 211-224.

Bell, S., Tyrväinen, L., Sievänen, T., Pröbstl, U., \& Simpson, M. (2007). Outdoor recreation and nature tourism: A European perspective. Living Reviews in Landscape Research, 1(2), 1-46.

Bragagnolo, C., Malhado, A.C., Jepson, P., \& Ladle, R.J. (2016). Modeling local attitudes to protected areas in developing countries. Conservation and society.14 (3). 163-182. https://doi.org/10.4103/0972-4923-191161 
Butler, R.W. (1980). The concept of a tourist area cycle of evolution: Implications for management of resource. Canadian Geographer. $24(1), 5-12$.

Cawley, M., \& Gillmor, D.A. (2008). Integrated rural tourism: Concepts and Practice. Annals of tourism research, 35(2), $316-337$. https://doi.org/10.1016/J.annals.2007.07.011

Çelik, S., \& Rasoolimanesh, S.M. (2021). Residents' Attitudes towards Tourism, Cost-Benefit Attitudes, and Support for Tourism: A Pre-development Perspective. Tourism Planning \& Development, 1-19. https://doi.org/10.1080/215683.2021.1873836

Ejiofor, A.T., \& Elechi, O.D. (2012). Assessment of the influence of education on tourism development in Enugu state, Nigeria. American Journal of Tourism Research, 1(1), 33-42.

Eshetu, A.A.(2014). Ecotourism as a viable strategy for livelihood diversification and sustainable natural resource management in Ethiopia (from eco-development paradigm point of view). Journal of Environmental Science and Water Resources, $3(2), 040$ - 052.

Fetene, A., Bekele, T., \& Tiwari, P.K. (2012). The contribution of ecotourism for sustainable livelihood development in the Nech Sar National Park, Ethiopia. International Journal of Environmental Sciences, 1(1), 19-25.

Gnanapala, A.C., \& Karunathilaka, T.P. (2016). Community perception on tourism development and its impacts: A study on Passikudha, Sri Lanka. Tourism, Leisure and Global Change, 3, 164-178.

Goharipour, H., \& Hajiluie, M.M. (2016). A study on river ecotourism development: Case study: Karaj River. International journal of Geography and Geology, 5(4), 73-85. https://doi.org/10.18488/journal.10/2016.5.4/10.4.73.85

Golubeva, E.I., Tulskaya, N.I., Tsekina, M.V., \& Kirasheva, N.I. (2016). Ecological tourism in protected natural areas of Russian arctect: prospects and challenges. Арктика и Север/arctic and north, N 23, https://doi.org/10.1723/ISSN 2221-2698

González-Ramírez, R., Gascó, J.L., \& Llopis, J. (2019). Local residents' perception about tourism and foreign residents: A Spanish case study. Journal of psycho mark. 1093-1108. https://doi.org/10.1002/mar.21259

Haloi, A.K., Misra, J., \& Hassen, M. (2017). A Critical Analysis on the Local Community's Attitude and Intention Towards Ecotourism and Conservation in Chakrashila Wildlife Sanctuary, Kokrajhar, Assam. International Journal of Engineering Technology Science and Research, 4(7). ISSN $2394-3386$.

Hanafiah, M.H., Jamaluddin, M.R., \& Zulkifly, M.I. (2013). Local community attitude and support towards tourism development in Tioman Island, Malaysia. Procedia-Social and Behavioral Sciences, 105, 792-800.

Harun, R., Chiciudean, G.O., Sirwan, K., Arion, F.H., \& Muresan, I.C. (2018). Attitudes and perceptions of the local community towards sustainable tourism development in Kurdistan regional government, Iraq. Sustainability, 10(9), https://doi.org/10.3390/su10092991

Kariuki, P. (2013). Local residents' attitudes and perceptions towards tourism development: a study of Lake Nakuru National Park and its environs, Kenya (Master's thesis, Moi University).

Long, J. (2007). Researching leisure, sport and tourism: the essential guide, SAGE Publication Ltd, London.

Mudimba, T., \& Tichaawa, T.M. (2017). Voices of local communities regarding their involvement and roles in the tourism development process in Victoria Falls, Zimbabwe. African Journal of Hospitality, Tourism and Leisure, 6(4), 1-15.

Nchor, A.A., \& Agbor, C.O. (2018). Local communities' attitudes and perceptions towards community based tourism in iko-esai community, cross river state, south east, Nigeria. International Journal of Research-GRANTHAALAYAH, 6(1), 69-79. ISSN- 23500530(O), ISSN- 2394-3629(P).

Poffenberger, M. (1996). Communities and forest management with recommendations to the intergovernmental panel on forests. Switzerland: IUCN.

soolimanesh, S.M., \& Jaafar, M. (2016). Residents' perception toward tourism development: A pre-development perspective. Journal of Place Management and Development. 9(1). 91-104. https://doi..org/10.1108/JPMD-10-2015-0045

Rasoolimanesh, S.M., Ringle, C.M., Jaafar, M., \& Ramayah, T. (2017). Urban vs. rural destinations: Residents' perceptions, community participation and support for tourism development. Tourism Management, 60, 147-158. https://doi.org/10.1016/ j.tourman.2016.11.019

Robbins, S.P., \& Coulter, M. (2005). Management. New Delhi: Prentice Hall.

Rua, S.V. (2020). Perceptions of tourism: a study of residents' attitudes towards tourism in the city of Girona. Journal of Tourism Analysis: Revista de Análisis Turístico. 27(2). 165-184. https://doi.org/10.1108/JTA-03-2019-0015

San Martín Gutiérrez, H., García de los Salmones, M.D.M., Herrero Crespo, A., \& Pérez Ruiz, A. (2018). Explaining residents' attitudes towards tourism and tourists: A new approach based on brand theory. International journal of tourism research. 20(2). 738-747. https://doi.org/10.1002/jtr.222

Tadesse, S.A., \& Teketay, D. (2017). Perceptions and attitudes of local people towards participatory forest management in Tarmaber District of North Shewa Administrative Zone, Ethiopia: the case of Wof-Washa Forests. Ecological Processes, 6(1), 1-16. https://doi.org/10.1186/s13717-017-0084-6

Teklie, S. (2011). Tourism Product Development in Hayik (North Central Ethiopia) (Master's Thesis, Addis Ababa University).

Tesfaye, S.S. (2017). Assessment of local community perception of and attitude towards Participatory Forest Management (PFM) system and its implications for sustainability of forest condition and livelihoods: the case of Chilimo-Gaji Forest in Dendi district, West Shewa zone, Oromia, Ethiopia. Journal of Earth Science \& Climatic Change, 8(1). https://doi.org/10.4172/2157-7617.1000382

Türker, A.N., \& Öztürk, A.S. (2013). Perceptions of residents towards the impacts of tourism in the Küre Mountains National Park, Turkey. International Journal of Business and Social Science, 4(2),101-114. http://www.ijbssnet.com/

Yamane, T. (1967). Statistics: an introductory analysis, (2nd ed.), Harper and Row, New York.

*** Amhara Culture, Tourism and Park Development Bureau, (2011). Discover Amhara tourist guide, Peacock Printers, Addis Ababa.

*** South Wollo zone culture and tourism office (2019). Tourist guide book, Natan printing, Dessie.

Article history: Received: 19.07.2021 Revised: 23.11.2021 Accepted: 15.12.2021 Available online: 31.12 .2021 